レーザー粉末溶融による消失模型作製の一方法

\author{
紙谷卓之, 山田修*, 丸谷 洋二 \\ 大阪産業大学工学部情報システム工学科 (テ574-8530 大阪府大東市中坦内3-1-1) \\ *大阪産業大学教養部（テ574-8530 大阪府大東市中垣内3-1-1）
}

\title{
A Method of Fabricating Evaporative Models by Selective Laser Melting
}

\author{
Takayuki KAMITANI, Osamu YAMADA*, and Yoji MARUTANI \\ Department of Information Systems Engineering, Faculty of Engineering \\ Osaka Sangyo University, 3-1-1 Nakagaito, Daito, Osaka 574-8530 \\ *College of General Education, Osaka Sangyo University, 3-1-1 Nakagaito, Daito, Osaka 574-8530
}

(Received February 28, 2001)

\begin{abstract}
In this paper, we propose a new method of fabricating evaporative patterns for vacuum molding and precision casting. Powders of exothermic reactive materials and salt are mixed uniformly and thinly spread. An infrared laser beam scans over the layer of these material powders. Chemical reaction occurs in the irradiated area, and the salt powders are melted by chemical reaction heat and laser energy. After the irradiation, the materials solidify and connect to the lower solidified layer. By repeating the powder spreading and the laser scanning, a 3-D model is fabricated. Since the main component of the model is salt, the model is easily removed from the mold hy washing with water. In order to prove this theory, simple layered models were made and their shapes were transferred to silicone rubber and plaster. Copies of the master models were made by vacuum molding and plaster molding.
\end{abstract}

Key Words: Selective laser melting, Rapid prototyping, Vacuum molding, Precision casting, Evaporative pattern

\section{1.はじめに}

注型法は, 液状の樹脂を型に注入し, 加熱, 冷却などによ り固化させて部品を作製する方法であり,プラスチック部 品の低コストな製造法として広く利用されている11) その 中の真空注型法は, 真空を利用して型の細部にまで樹脂を 均一に充填する成形法である。そこでは型素材としてシ リコンゴムが多く用いられており, 模型の周囲を液状のシ リコンゴムで包み, 硬化後メスで分割して中の模型を取り 除き, 再度組み合わせて型とする2)。

精密鋳造法は, 模型を元に作製された型に金属を鋳込む ことにより,形状を置換して金属部品を製造する方法であ る3). そこでは原模型 (消失模型)の素材としてワックス (ろう)が多く用いられており,模型の周囲を泥状の鋳型材 料で包み, 材料が固化した後, 加熱してワックスを溶かし 出すことによって鋳型が作製される.

3次元CADの普及にともなって,これら真空注型や精密 鋳造の原模型を設計データから直接に光造形法4,5)によっ て樹脂で作製する試みがなされるようになった6). 光造形 法とは, 液状の光硬化性樹脂の上を紫外線レーザーで走査 して薄い硬化層を形成することと,この硬化層を一層の厚
さ分だけ液中に沈めることとを繰り返して, 積層模型を作 製する方法である。真空注型の原模型を光造形法で作製 した場合は,複雑な構造であると模型を取り外す際にシリコ ンゴムが模型に食いついて,ちぎれるという問題があり7), 脱 型にはかなりの熟練が必要である。また, 光造形に用いる 樹脂は装置メーカーが供給する特殊なものであって, 注型 用のエポキシ樹脂などに比べるとはるかに高価なもので ある.したがって, 光造形法でプラスチック部品を大量生 産することは採算に合わないし, 1個の原模型から複数個の 製品を作製する注型法の場合であっても，もっと安価な素 材を利用できることに越したことはない. 精密鋳造の原 模型を光造形法で作製した場合には, 脱型は燃焼あるいは 溶融後に燃焼することによって行われるが, 燃焼ガスの発 生や模型が熱膨張することにより鋳型が破損したり, 鋳型に 灰が残留し鋳物に悪影響を及ぼすという問題があり ${ }^{7-9)}$, 脱 型にはやはり高度な熟練が必要である。また, 燃焼ガスの 毒性や前述の樹脂価格の問題もある.

無害で安価な物質として水を用いて注型用の原模型(消 失模型)を作製するRapid Freeze Prototyping (RFP) と呼ばれ る方法が提案されている10).この方法では, 水を低温の雾 囲気下で滴下しつつ水結させ, それを堆積させていくこと 
によって氷の立体模型を作る。しかしながら室温での作 業ができない上, 水滴が氷結してできる単位水結体のサイ ズが不安定なため, 上下方向の寸法精度が期待できないと いう難点がある.

型を使わずに光造形法のようにレーザーを用いてCAD データから金属模型を作製する手法がいくつか検討され ている6). 粉末焼結法11)は,バインダでコーティングした 金属粉末を薄く敷き詰めることと,その上を赤外線レー ザーで走査することとを繰り返して積層する方法であ る。しかしながら金属粉末がバインダで仮に固定されて いるだけであるので, 模型にするためには融点近くの高温 で焼結を行う必要がある。そのため, 作製に時間がかかる だけでなく焼成工程に関する高度な熟練を要することが問 題となっている。グリーンテープレーザー焼結法 ${ }^{12)}$ は, 材 料粉末とバインダとで作製したテープを利用し,レーザー 焼結とテープの供給を繰り返して積層する方法であるが, 模型の強度と密度が問題とされている. Laser generating ${ }^{13)}$ は,レーザーの照射位置に金属粉末をふりかけて, 粉末を加 熱, 溶融して直接造形していく方法であるが, 大出力のレー ザーが必要であり,オーバーハング形状を造形できないと いう問題もある。レーザープロトタイピング14) は, 金属粉 末の敷き詰めと赤外線レーザーの走査を繰り返して積層 する方法で,粉末を溶融にまで至らせて金属模型を直接造 形するものである。しかしながら寸法精度の向上, 熱によ る変形や残留応力などが問題点として残されている。

ここでは食塩を主成分とした粉末をレーザー走査し, 選 択的に溶融・再凝固した層を積み重ねて立体模型を作製 する方法を試みた。食塩は水溶性であるので, 水洗いによ り型を破損することなく模型を除去でき, 脱型の工程に高 度な熟練も焼成炉などの設備も不要になる，また, 水洗い に用いた排水を再処理する必要がなく,素材の価格も安価 であるなどの特長がある。以下, 模型作製の原理と, 粉末 の溶融と積層の実験, 注型と鋳造の簡単な実証実験を行っ た結果について述べる。

\section{2. 模型作製の原理}

積層造形は, 立体模型を作製する手法の一つである．3次 元形状を表すデジタルデータをもとに, 等間隔に平行な平 面で切断して断面形状を求め, 薄い固体層を断面形状にし たがって形成し，順次に積層して全体を作製する15)。本研 究では固体層を形成する手法として, Fig.1のように粉末状 素材を敷き詰めて赤外線レーザー光で選択的に溶融・再 凝固させる方法を用いた。食塩 $(\mathrm{NaCl})$ の融点は $800^{\circ} \mathrm{C}$, 沸 点は $1467^{\circ} \mathrm{C}$ であるから, 食塩粉末を融点以上かつ沸点未満 の温度になるよう加熱すれば, 食塩粉末を溶融させること ができる。しかしながら固相の食塩は, 局所加熱用レー ザーとして代表的な $\mathrm{CO}_{2}$ レーザーの発振波長10.6 る透過率が厚さ $10 \mathrm{~mm}$ の場合で $91 \%$ と非常に高く16), レー ザー光を照射して食塩を溶融することは容易ではない. そこで反応性の素材を食塩に混合し, 素材によるレーザー 吸収熱に化学反応熱を付加することによって食塩を溶融 することを試みた。収束した赤外線レーザービームに

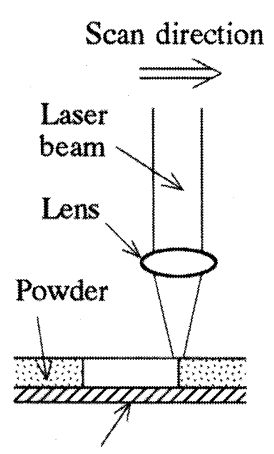

Base plate

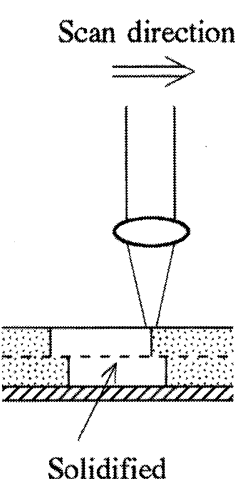

(b) layer 2

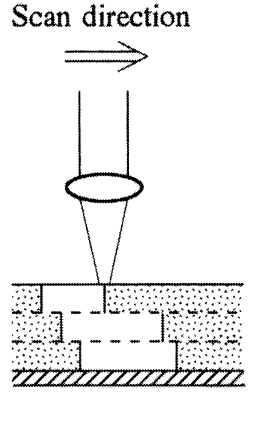

(c) layer 3

Fig.1 Selective laser melting.

よって食塩と反応性素材の混合粉末上を走査する。レー ザー照射部では, 反応性素材が熱エネルギーを吸収して化 学反応を起こし, その化学反応熱が素材のレーザー吸収熱 に加えられて食塩粒子の表面が溶融する。走査後は冷却 され, 隣り合う粒子同士が接合して, 走査軌跡形状の凝固 物が形成される。凝固層の上にさらに混合粉末を薄く敷 き詰めてレーザー走査することにより,断面形状を形成さ せつつ下層との接合を行う。このようにして粉末の敷き 詰めとレーザーの走査を繰り返し行うことにより, 食塩を 主成分とした立体模型が作製される．粉末を積層してか ら部分溶融する方法であるので, 垂下部を造形する際に下 カからのサポートを設ける必要が無い.

\section{3. 模型作製の基礎実験}

\section{1 実験装置}

Fig.2に実験装置を示す。レーザービーム走査装置とし てレーザーマーカー(LP-110：サンクス(株))を利用した. このレーザーマーカーは, レーザーヘッドとコントロー ラーで構成され, レーザーヘッドには発振波長 $10.6 \mu \mathrm{m}$, 最 大出力 $20 \mathrm{~W}, \mathrm{TEM}_{00}$ モードの $\mathrm{CO}_{2}$ レーザーが備えられてい る.ビーム走査方式は, 2 軸ガルバノスキャニング方式であ る. ビーム出射口の下方に, シリンダーを固定し, そのシ リンダー内部には上下方向に可動する円形テーブルを配 置した。シリンダーヘッドからテーブルを所望の高さだ

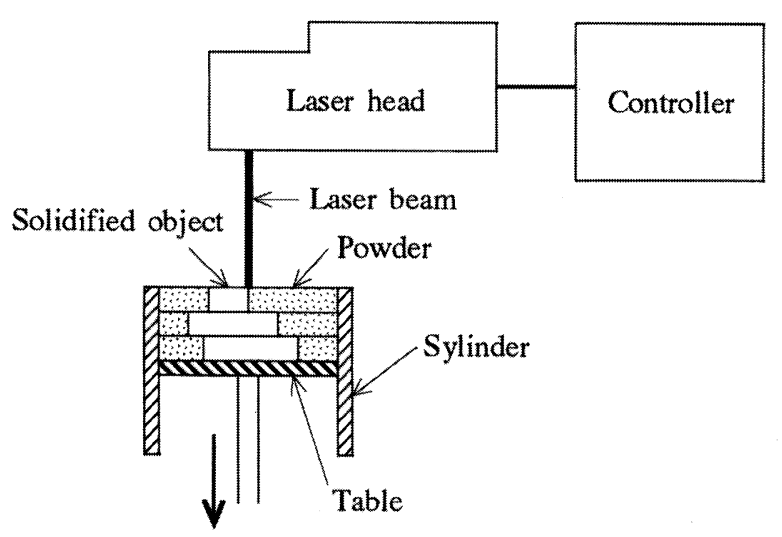

Fig.2 Experimental system. 
け降下させ,そこに素材である食塩と反応性素材の混合粉 末を敷き詰め，その上からレーザービームを照射する．照 射位置におけるビームスポット径は理論值で $110 \mu \mathrm{m}$ であ る. 食塩は市販されているままでは粒径が大きいので, ミ ルにより粒径 $100 \mu \mathrm{m}$ 程度に粉砕し, 充分乾燥させたものを 用いた。

パソコン上のCADソフト (CANDY6：(株)アスキーサム シンググッド)で作成した形状データをレーザーマーカー に転送し,レーザーパワーと走査速度を設定した後に走查 を開始させる。これによりレーザービームで粉末上に所望 の形状を描くことができる。

\section{2 食塩のみによる部分溶融実験}

本手法ではレーザーを走査した範囲が溶融・再凝固し， かつ凝固層間が接合する必要がある。そこでまず, 反応性 素材無しの場合について部分溶融実験を行った，実験装 置のテーブル上に食塩粉末を厚さ $3 \mathrm{~mm}$ で敷き詰め, その上 を出力20Wのレーザービームで走査した．しかしながら， やはり食塩の赤外線透過率が高いため, 走査速度を $1 \mathrm{~mm} /$ secまで遅くしても粉末には何ら影響がなく, 部分的な溶融 が起こらないことがわかった。

\section{3 発熱反応性素材の混合による部分溶融実験}

小出力レーザーにより実用に供するレベルの走査速度 で食塩を溶融させるためには, 熱を充分に吸収するような 素材を混合するか, レーザー光の照射によって発熱するよ うな素材を混合する必要があると考えられる。ここでは レーザー照射エネルギーの低減をねらって後者を選択し， 発火をともなう発熱反応の一つである燃焼合成 ${ }^{17)}$ の起こ る素材の粉末を混合した。また食塩の沸点を考慮し,燃焼 合成の中では生成熱の比較的小さな $\mathrm{Cu} \mathrm{Al}_{2} \mathrm{O}_{3}$ の混合体を 合成する系を選択した。この燃焼合成の化学反応式は

$$
0.3 \mathrm{CuO}+2.7 \mathrm{Cu}+0.2 \mathrm{Al} \rightarrow 3.0 \mathrm{Cu}+0.1 \mathrm{Al}_{2} \mathrm{O}_{3}
$$

で表され，標準生成熱は $-\Delta H f=38.8 \mathrm{~kJ} / \mathrm{mol}$ である，素材中 のCuは, 発熱量を制御する目的で非反応物質としてあらか じめ添加した生成物である。平均粒径がそれぞれ $\mathrm{CuO}: 1$ $\sim 2 \mu \mathrm{m}, \mathrm{Cu}: 15 \mu \mathrm{m}, \mathrm{Al}: 27.6 \mu \mathrm{m}$ の粉末を, モル比でそれぞ れ10\%,84\%,6\%にして混合した。

まず, 反応性素材の粉末と食塩粉末を重量比で1：3に混 合してテーブル上に厚さ $3 \mathrm{~mm}$ で敷き詰め, その上から $16 \mathrm{~W}$ のレーザービームを $1 \mathrm{~mm} / \mathrm{sec} の$ 速度で走査した. 走査軌跡 は2つの楕円を交差させた形状とした。レーザー光が照射 されると, 照射領域の反応性素材に瞬時に着火し,レーザー による加熱に化学反応熱が付加されて食塩粉末の表面が 溶融する，走査後は自然冷却により即座に凝固し，粉末同 土が固着する．Fig.3に走査終了後のシリンダ内の凝固物 と周囲の粉末素材の様子を示す。図より交差部分も含め て走査領域全体が固着していることがわかる。このよう に反応性素材を混合して熱を補えば, 小出力のレーザーで も食塩を溶融可能であることがわかった。

本手法は, 細いビームを用いた非接触加工であり, 切削 加工のような力学的加工に比べて原理的に壁が薄く寸法

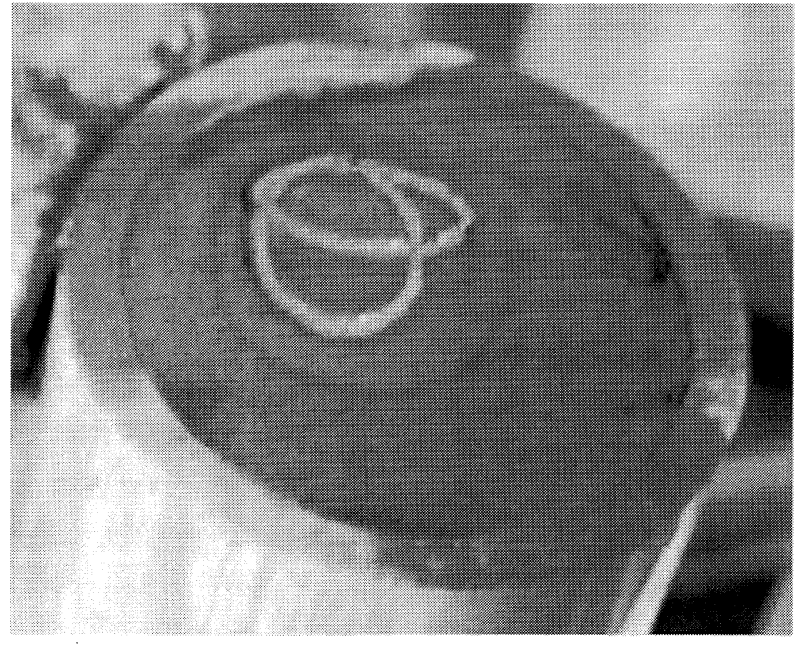

Fig.3 An solidified object and powders around it. (reactive materials : salt $=1: 3$ in weight ratio, laser power: $16 \mathrm{~W}$, scanning speed: $1 \mathrm{~mm} / \mathrm{sec}$ ).

精度の高い模型を作製できる。そこで次に, 壁の厚さや寸 法精度に直接関係する凝固幅に対して, 反応性素材粉末と 食塩粉末の混合比やレーザーエネルギーが与える影響を 調バた。ここで凝固幅とは, 凝固物の上面寸なわち深さ0に 扮ける走査軌跡の接線に垂直な方向の寸法をいう. Fig.4 (a)〜 (c)にビームスポット径が $110 \mu \mathrm{m}$ の場合の実験結果を

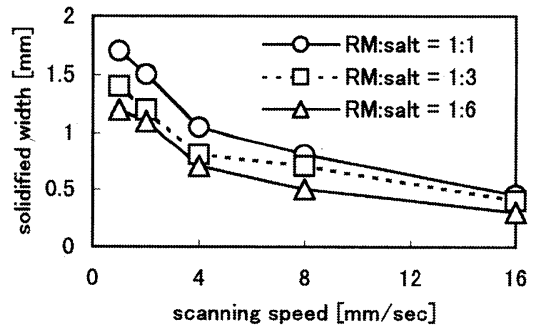

(a) laser power: $16 \mathrm{~W}$

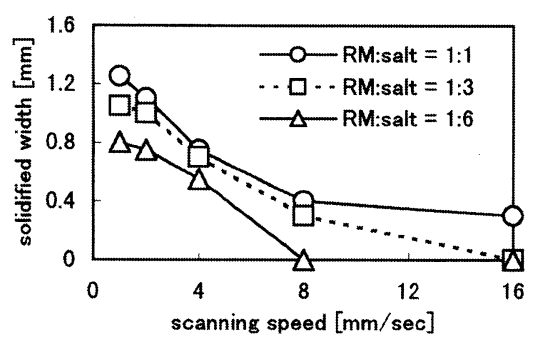

(b) laser power: $8 \mathrm{~W}$

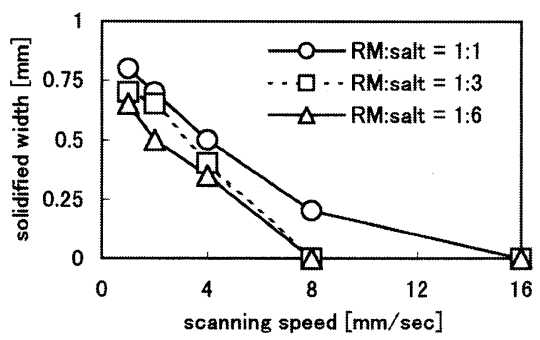

(c) laser power: $4 \mathrm{~W}$

Fig.4 Relationship among laser power, scanning speed, mixing ratio, and solidified width. $(\mathrm{RM}=$ Reactive Materials). 
示す. 図より次のような傾向のあることがわかった.

(1) 反応性素材の混合比が高いほど, 食塩粉末の溶融に必要 なレーザーエネルギー $[\mathrm{W} / \mathrm{mm} / \mathrm{sec}]$ が小さく, 凝固幅も大 きい.

（2）反応性素材の混合比が同じ場合，レーザーエネルギー

[W/mm/sec]が大きいほど, 凝固幅が大きい.

発熱エネルギーは反応性素材の混合比に比例する。 よって凝固幅を狭くして精密な模型を作製するのであれ ば, 熱エネルギー, すなわちレーザーエネルギーや反応性 素材の混合比を小さくすれば良い.

\section{4 積層実験}

反応性素材粉末と食塩粉末を重量比で1：3に混合した 材料を用いて,次の3つの工程を繰り返し行うことにより積 層模型の作製を試みた。

(1)テーブルを1層分の高さだけ降下させる

(2)粉末を敷き詰める

(3)ビームを走査する

3.3の結果をもとに実験条件を次のようにした。

$$
\text { レーザーパワー：16W }
$$

走査速度： $1 \mathrm{~mm} / \mathrm{sec}$

層厚み: $0.5 \mathrm{~mm}$

Fig.5に積層数を 10 として作製した模型の例を示す。困の ように上下層間が接合され,安定に造形されていることが わかる。粒径が $100 \mu \mathrm{m}$ 程度の食塩を用いて作製したので， 表面に凹凸のある模型となった。もっと細かく食塩を粉 砕すれば, 空隙を少なくして敷き詰めることができ，また 粒径が小さい分だけ模型表面の凹凸も小さくできるので， 寸法精度を向上できると考えられる。一層当りの走査時 間は約77秒で, 手作業で行ったテーブルの降下と粉末の敷 き詰めに一層当り約50秒要し,模型全体の作製時間は約 22 分であった．燃焼合成を起こす素材には様々な物があり， より生成熱の大きな反応性素材を用いれば, 走査速度を速 めてレーザー熱エネルギーを小さくしても, 食塩が溶融す る可能性がある。素材選定による走査速度の向上と工程 の自動化を行えば,作製時間の短縮が望める.

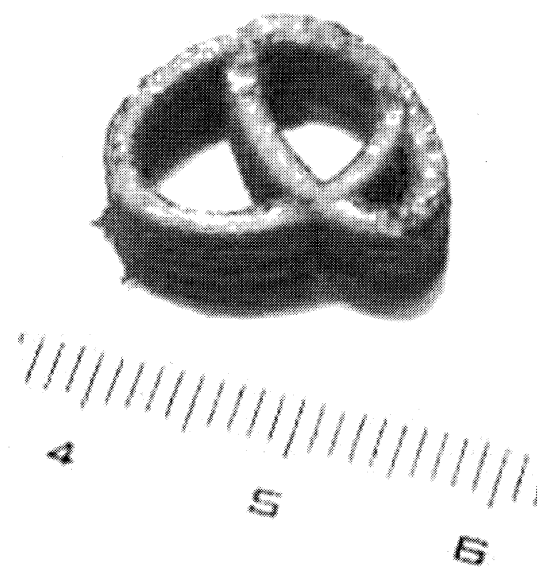

Fig.5 An example of the layered model.

\section{4. 形状の転写と複製}

ここでは, 注型や鋳造への応用の可能性を調べるため, シ リコンゴムおよび石膏への形状の転写を試みた。

4.1 シリコンゴムへの転写と注型

まず液状のシリコンゴム (シームレスシリコン：国際ク ラフト(株))で積層模型を覆い, シリコンゴムを真空槽内で 充分脱泡した後, 恒温槽内で硬化させた。次に模型の外周 囲のシリコンゴムをメスで切開し, 全体を水に漬けて水洗 いした，反応生成物である $\mathrm{Cu}$ と $\mathrm{Al}_{2} \mathrm{O}_{3}$, および未反応の状 態で残った $\mathrm{CuO}, \mathrm{Cu}, \mathrm{Al}$ の粉末は, 模型の中に点在していた が, 構造材料である食塩が溶け出すことにより,これらも 切開部分から細かい粒塊として流れ出た。模型の除去に 要した時間は2〜3分であったが, 温水を用いれば除去時間 は短縮できると考えられる. 模型除去後, 模型の内側部分

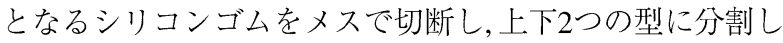
た。これらを再度組み合わせ, 内部にエポキシ樹脂 (GM9002：(有)ブレニー技研)を注入し, 加熱して樹脂が硬化し てから型を外した。 Fig.6は, 積層数7の模型から作製した 注型品である。図に示すように水溶性模型を元にして注 型品が作製できることを確認した。

\section{2 石膏への転写と鋳造}

食塩を主成分とした模型はそのままでは潮解性がある ので,まず初めにフッ素系離型材 (ダイフリーA741：ダイ キン工業(株))で積層模型表面をコーティングした。次に 模型の下半分を石膏で覆って固化させ, 境界面に当たる石 亳面に離型材を塗布して,さらにその上から石膏を流し込 んで模型を完全に覆った，石膏が固化した後, 溶融金属を 流し込む湯口から模型表面のコーティングの一部を破り， 全体を水につけて4.1と同様にして内部の模型を洗い出し た. 境界面で上下 $2 つ 0$ 型に分割し, イソプロピルアルコー ルで洗浄して型の内側と境界面の離型材を除去した。こ れらの型を恒温槽内で乾燥させてから組み合わせ, 溶融し た鉛を流し込んだ。最後に型を外して中身を取り出し た. 以上の手順によって, 積層数10の水溶性模型からFig.7

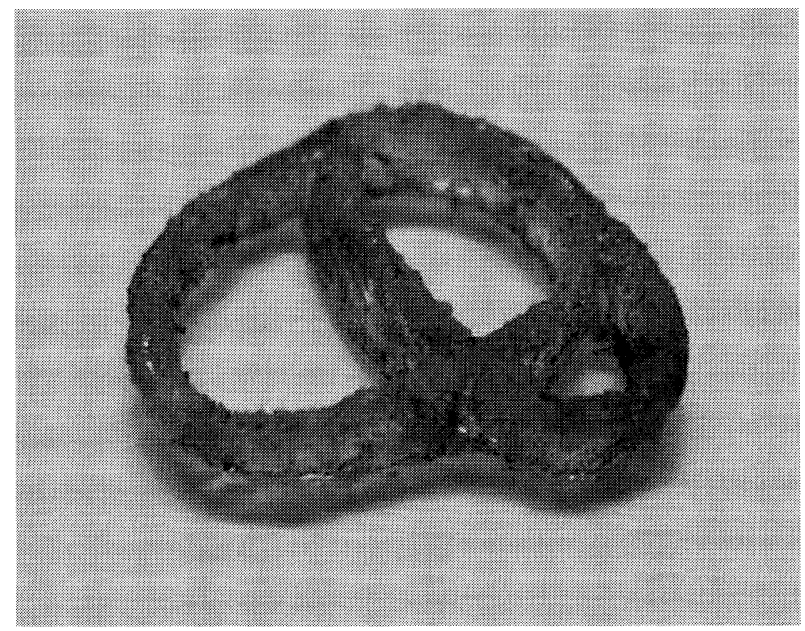

Fig.6 An example of the plastic molding. 


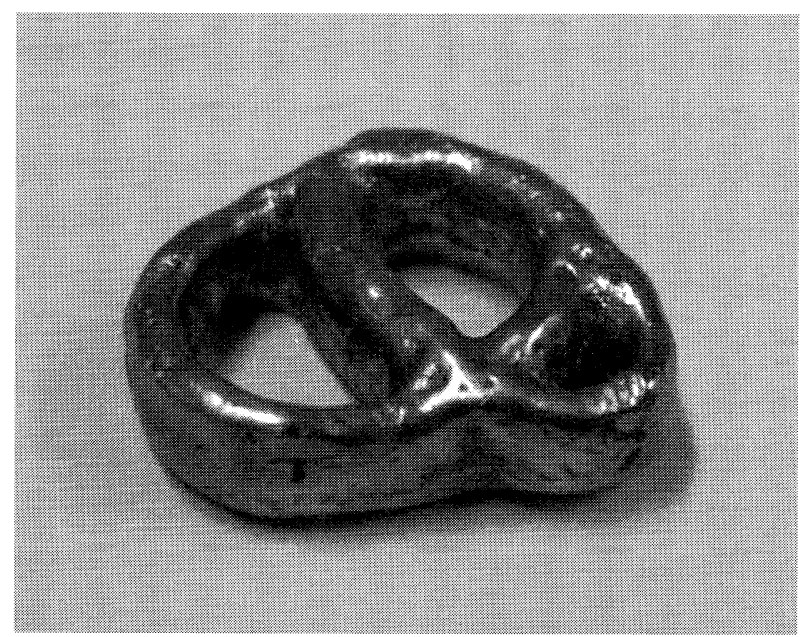

Fig.7 An example of the lead casting.

に示す鋳造品が作製できた。溶融金属が型の隅々にまで 充分に行渡らなかった形跡が見受けられるが,これは溶融 金属の温度が低く,その表面張力や粘度が大きかったこと， ならびに湯口が短か過ぎて湯口部分の溶融金属の重力た けでは,型内部の溶融金属に充分な押圧を加えられなかっ たことなどによると推測される．金属を充分加熱して流 動性を高めてから型に流し込むことと, 湯口を長くする, あ るいは湯口の上に湯溜り（溶融金属の溜り）を設けるなどし て型内部に溶融金属を充分に押し込んでやることにより， 鋳造の精度を向上できると考えられる。

\section{5. あとがき}

注型および鋳造用の原模型 (消失模型)の作製を目的と して, 赤外線レーザーにより食塩を主成分とする粉末を選 択的に溶融 - 再凝固させて積層模型を作製する方法を提 案した．食塩は赤外線透過率が高く単独ではレーザー走 査により溶融することが難しいので, 燃焼合成と呼ばれる 化学反応を起こす素材粉末を混合し, その反応熱を付加す
ることにより溶融させた。この模型は主成分が食塩であ るので, 模型周囲を型材料で覆った後に水洗いすれば, 型 から簡単に除去することができる，提案方法の実証を目 的として実際に簡単な積層模型を作製し, その形状をシリ コンゴムと石膏に転写した。さらに, それらの転写型を利 用して注型品, 鋳造品を作製した。今後の課題として, 積層 模型の寸法精度の向上と作製時間の短縮とがあげられる。

\section{参考文献}

1）(社)高分子学会編：プラスチック加工技術ハンドブック（日 刊工業新聞社, 1995).

2) 中川 威雄：型技術 12 (1997) 18.

3) (社) 日本機械学会：機械工学便覧応用編 B2 加工学 · 加工機 器 (丸善, 1984).

4) 中井孝, 丸谷洋二：レーザー研究 16 (1988) 14.

5) 丸谷洋二, 中井孝：レーザー研究 17 (1989) 410 .

6) 丸谷洋二：レーザー研究 24 (1996) 467.

7) 門格史, 原 信彦, 吉村一彦, 中下 和俊：第16回ラピッドプロ トタイピングシンポジウム講演論文集 (1999) p.125.

8）村松 磐, 䇾輪 幸三, 笹川 俊夫, 増田 伸二, 孟 陽：第16回ラ ピッドプロトタイピングシンポジウム講演論文集（1999） p.101.

9) 清水 竜朗, 渡辺 徹哉, 後藤 基浩, 小永 幹夫, 鈴木 朝夫 : 第 19 回ラピッドプロトタイピングシンポジウム講演論文集 (2000) p.71.

10) W. Zhang, M. C. Leu, Z. Ji, and Y. Yan: Solid Freeform Fabrication Proceedings, Austin, 1998 (The University of Texas at Austin, 1998) p. 185.

11) S. Das, N. Harlan, J. J. Beaman, and D. L. Bourell: Solid Freeform Fabrication Proceedings, Austin, 1996 (The University of Texas at Austin, 1996) p.89.

12）前川 克廣, 小川慧, 大島 郁也, 横山 雄一: 精密工学会誌 64 (1998) 1340.

13) W. König, T. Celiker, and H. J. Herfurth: Proceedings of the 2nd European Conference on Rapid Prototyping and Manufacturing, Nottingham, 1993 (The University of Nottingham, 1993) p.303.

14) F. Abe and K. Osakada: International Journal of the Japan Society for Precision Engineering 30 (1996) 278.

15) 中川 威雄, 丸谷 洋二 編著: 積層造形システム (工業調査会, 1996).

16）福見 俊夫,安井至,植月 正雄編：光学材料ハンドブック（(株) リアライズ社, 1992)

17）山田修：科学と工業 65 (1991) 460 . 